MSC 90C05

DOI: $10.14529 /$ jcem 150401

\title{
RESULTS OF PATENT AND ANALYTICAL REVIEW OF THE PROBLEM OF COMPLEX STRUCTURED MIXTURE TRANSFORMATION
}

O.S. Logunova ${ }^{1}$, logunova66@mail.ru, N.S. Sibileva ${ }^{1}$, natus224@gmail.com.

${ }^{1}$ Nosov Magnitogorsk State Technical University, Magnitogorsk, Russian Federation.

\begin{abstract}
Results of patent and analytical review of the task of complex structured mixture transformation are demonstrated and classified in the paper. The selection and analysis of the most effective science and technological solutions in area of the research are analyzed. The search and selection of the most important periodical sources for research (including foreign sources) are also demonstrated. The generalized diagrams of scientific sources analysis by the imprint date and by the publishing country are show as a system analysis. The results, obtained during the research, allowed to get the adequate representation about the current developments in the field of complex structured mixtures, to determine the degree of field developments, and also to plot a vector for the further work in this research.

Keywords: patent and analytical review; multi objective optimization; linear programming; complex structured mixture.
\end{abstract}

\section{Introduction}

There are so many different branches of industry and national economy, where the complex structured mixtures are exists, especially nowadays. At the specific stages of production, some actions are inevitably influence on mixture and after that it changes its own structure and composition. In this context, the works is inevitable to identify interrelations between structure and composition of the mixture at the input and at the output. However, very often it's impossible to describe analytically the process of changing the mixture structure and composition, that is why, the research of the empirical data, received in help with the process monitoring, is necessary for each individual case with complex structured mixture in order to build a mathematical model of the task. It is evident that every mathematical model will have its own distinctive characteristics, which depend on the use of complex structured mixture, on the type of conditions, and on the influence to the mixture. The authors of the paper [1] developed a universal model for representation the composition of complex structured mixture, which is changes due to some influences. This model has been successfully applied to the task of determining the structure of charge materials for electric arc furnace. This allowed the developing of a mathematical model of formation the residual elements (chromium, nickel and copper) in the steel, consisting of two sequential multi-criteria optimization tasks [2]. This task has been solved with the tree methods of multi-criteria optimization and the comparative analysis of the decisions has been made [3]. Considering the successful model testing on the task of the charge materials composition optimization, it was decided to develop a universal software for forecasting the composition of the complex structured mixture and 
for identifying the interrelations between the mixture structure at the input and at the output on the basis of work with empirical data. That is why, it is necessary to analyze and evaluate the existing solutions in the field of working with the complex structured mixtures and to research the condition of the problem by the periodical sources in order to determine the current level of technology, as well as the trends of further works with the mixtures. Examples of these solutions are:

1) search and selection of the most effective scientific and technological achievements;

2) search and selection of the most important periodical sources for the research (including foreign publications);

3) systematization and analysis of selected materials. The two large researches of the problem state: patent and analytical have been conducted for the goal achievement. Lets review the results, which were received during the researches.

\section{The Results of Patent Research}

In the period from $06 / 03 / 2015$ to $29 / 03 / 2015$ the search and analysis of patents, claims for inventions and for utility models have been implemented, and the search of registered software for ECM and data bases has been implemented also [4]. Patent search by the methods of determining of the mixture composition and by the ways of mixing the components allowed to find 12 analogs. Among them:

1) 5 patents for inventions. The earliest patent for invention was registered in 1971, the last one, which was suitable for the research topic - in 2012.

2) 4 applications for inventions. Claims were registered in the period from 2002 to 2005.

3) 4 registered software for the ECM. Software was registered in the period from 2014 to 2015. Analysis of selected materials showed that existing solutions are applicable only for the individual steps of solving the task of complex-structured mixture transformation. In particular, "The device for controlling the batching" ensure the increasing accuracy of the batching the components of the complex mixture, but not provide the opportunity of the calculation the mixture composition at the input and at the output [4]. However, the device uses an automatic control of the compliance its weight to the mixture formula, thus the process state monitoring is executed, as in the case of the author's task. "Device for selection an optimal solutions" [4] allows to select the optimum solution not only in the system exploitation process, but also in the process of its development. However, there are no opportunities for determining the predicted values in this device also. But, in this device the method of the main criterion is used for solving the task, whose applicability has been tested on the problem assigned by the authors. "Analog device for calculation the composition of the complex mixture in percent" [4] allows to determine the percentage composition of the mixture, but it is the only opportunity of the device. The analysis allowed to consider a variety of devices for solving optimization tasks. It will help in future to test the solution methods, which are used in the devices, on the problem of determining the structure of the charge materials. In addition, the analysis allowed to ensure the that the interest of determining the mixture compositions is appeared a long time ago, but the existing technical solutions are not universal and do not allow to implement the ways of organization the prediction process of the complex structured mixture composition, specifically the identification some interrelations between the input and output system 
parameters in the process of changing the control actions. In connection with this, the own development of software for calculating the predicted values of the complex-structured mixture parameters for solving the task of the complex-structured mixture transformation is necessary and has no existing analogues.

\section{The Results of Analytical Research}

According to research of the complex-structured mixture transformation task there were analyzed the 51 periodical sources, among them the 20 articles written by the Russian authors and the 31 by the foreign authors. Most of the Russian scientists works are concentrated within the 1980 - 2000 gg., but the foreign authors began to publish works on multi-criteria optimization relatively recently, and most of the works are dated by 2015 .

For the works of the foreign authors, such as F. Le Huede and N.D. Pankratova, the scientific novelty of the methods of solution the multi-objective optimization tasks, making its own contribution to the task solution and the development of the hybrid methods for solving the tasks is specific, for example works [5, 6]. For the Russian scientists' L.A. Rastrigin and A.V. Timofeev works is typical to research the existing methods and to make the attempts for classification them according to different criteria $[7,8]$. In the research of Russian scientists a great attention is given to the methods of solving multi-criteria optimization based on convolution of the criteria (in particular, the pairwise convolution of criteria), and ranking them by importance, that is, reducing the task from the multi-criteria optimization task to the one-criterion optimization task [9-11]. The research of different multi-criteria methods application is being carried out by both Russian and foreign scientists. For example, the authors C. Zopounidis and M. Doumpos from Greece are evaluate the financial risks using the models, which are containing the milti-objective optimization methods [12], and scientists from the USA apply the multicriteria optimization techniques in the oil industry [13]. An important part of the research is carried out to research of multi-criteria optimization tasks under uncertainty. The works of the authors Yu.M. Volin and L.G. Gurin are focused exactly on this. According to this analysis we can make two main conclusions:

1. The analysis allowed to investigate the different multi-objective optimization methods. At the same time, the applicability of some methods for solving the problem of determining the percentage of residual elements in the steel, such as the method of concessions, the method of restriction and the method of criteria convolution have already been tested in [3]. Having a lot of other methods makes it possible to check the possibility of using them for solving the same problem, as well as an opportunity of finding more appropriate solutions than those that were obtained by three methods listed above.

2. Taking into account the fact that the authors of [1] have developed a universal model of representation of the composition of complex-structured mixture, and the fact that it has been applied only to represent the structure of the charge material for electric arc furnace, makes the analysis needed to identify other applications of the complex structured mixtures. During the analysis a large number of fields using complex-structured compounds were found and it can be possible to use the same model for a more convenient and visualize the structure of the mixture. 


\section{The Bibliometric Evaluation of Researches}

The comparative charts were built to perform the system analysis of the analytical research results in the field of multi-objective optimization and complex-structured mixtures. Figure 1 is represents the chart of the distribution of the scientific papers by the country of its publication. Based on the chart shown above, we can conclude that the research topic causes the interest and studied widely in different countries.

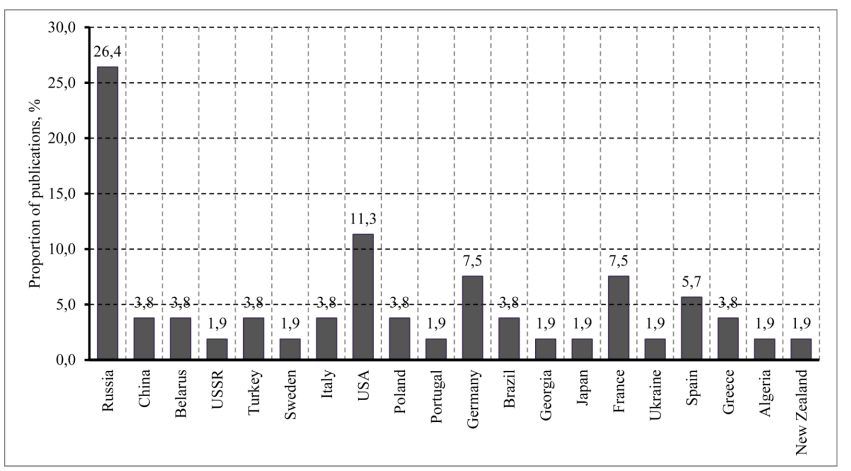

Fig. 1. The chart of the distribution of the scientific papers by the country of its publication (in percentages of the total amount of papers)

According to research, there were founded the 51 periodical sources, among them: 14 in Russia, 6 in USA, 2 in China, 6 in USSR, 2 in Turkey, 1 in Sweden, 2 in Italy, 2 in Poland, 1 in Portugal, 4 in Germany, 2 in Brazil, 1 in Georgia, 1 in Japan, 4 in France, 1 in Ukraine, 3 in Spain, 1 in Algeria and 1 in New Zealand. Also, the systematic analysis of the publication activity of the research topic allowed to build a chart of distribution scientific papers by the year of publication. This diagram is shown in figure 2 .

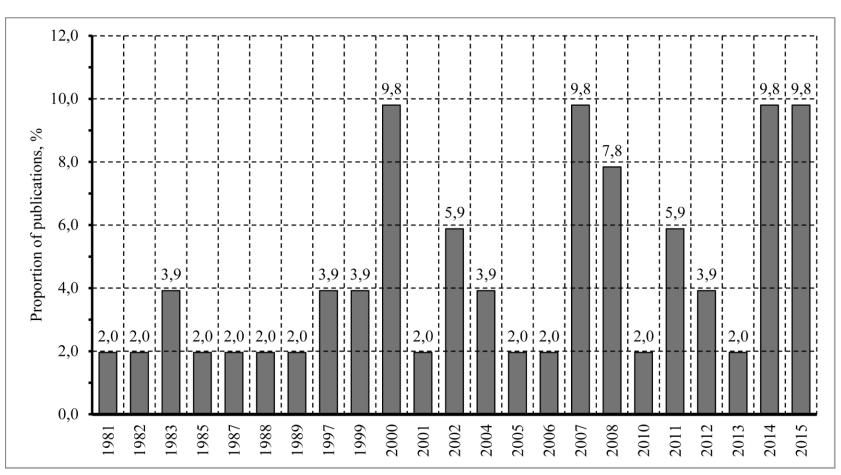

Fig. 2. The chart of distribution scientific papers by the year of publication (in percentages of the total amount of papers)

As the figure shows, the theme has sparked interest in 2000, 2007, 2008, 2014 and 2015. The first works, which can be attributed to the analysis of the task of the transformation the complex-structured mixture, are dated by the 1981, so, this topic is relevant for almost 40 years. Analysis of the research in the field of working with multi-criteria optimization tasks showed that until now the attempts to classify the existing methods of multi-criteria optimization and development of new ones are made. At the present time the methods 
for solving multi-criteria optimization tasks under uncertainty, the methods for solving multi-criteria optimization tasks based on neural networks and the other methods that are utilized in different fields are developed. The scheme of classification the existing researches in the field of work with the tasks of multi-criteria optimization is shown in Figure 3.

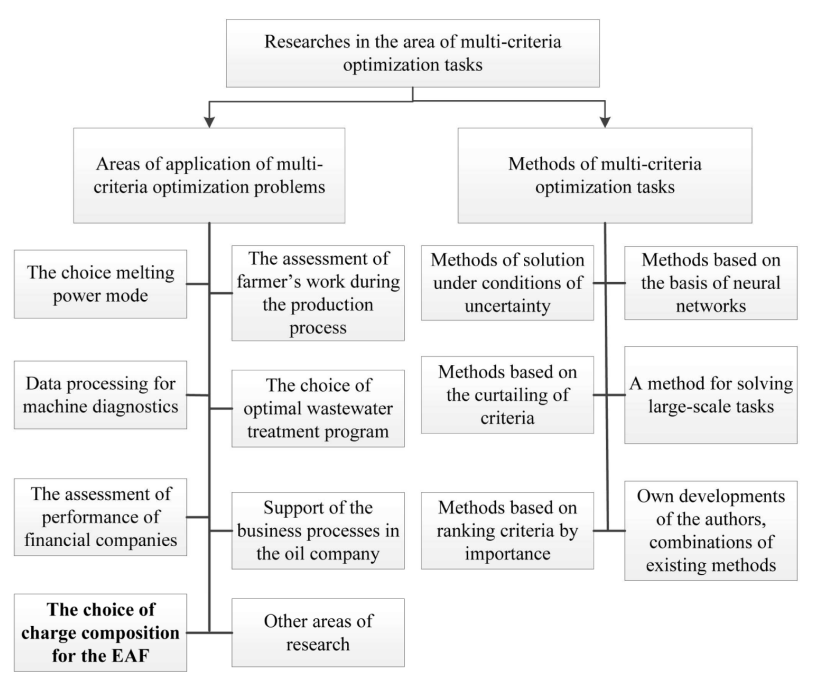

Fig. 3. The scheme of classification the researches

In terms of classification, shown in Figure 3, master studies related to the research of the applicability of the known methods of multi-criteria optimization to predict the composition of the charge material for electric arc furnace.

\section{Conclusion}

The authors of the paper are made the analysis of the patent and analytical research of the task of the complex structured mixture transformation. Patent search by the task of transformation the composition of complex structured mixture allowed to find 12 analogies. At the same time, the existing solutions are suitable for individual stages of solving the problem of the transformation of complex-structured blend, and research is needed to develop a common method of working with mixtures. In addition, the review of the periodical sources was made and the 51 source by the research topic was found. Analysis allowed to reveal possible areas for the application of the developed methods to predict the composition of complex-structured mixture. In addition, variety of methods of multi-criteria optimization has been analyzed. It is necessary to make a further analysis, justification of advantages and disadvantages and possible applications of the task of predicting the composition of complex-structured mixture on the example of the calculation of the structure of the charge material for electric arc furnace.

\section{References}

1. Sibileva N.S., Logunova O.S., Pavlov V.V. Set-Theoretical Model of Interaction between the Components in the Complex Structured Mixture. Automation of Technologies and Production, 2015, no. 2 (8), pp. 25-27. 
2. Logunova O.S., Filippov E.G., Pavlov I.V, Pavlov V.V. Strategy of the Formulation the Task of the Multi-Objective Optimization of the Charge Materials Composition for Electric arc Furnace. Steel in Translation, 2013, vol. 43, no. 1, pp. 34-38.

3. Logunova O.S., Sibileva N.S., Pavlov V.V. The Results of Comparative Analysis of Solving Multicriteria Problems Optimization for Calculation the Structure of Charge Materials for Electric arc Furnace. Software of Systems in the Industrial and Social Fields, 2014, no. 2, pp. 54-64.

4. Federal Institute of Industrial Property (FIPS), available at: http://www1.fips.ru (accessed 13 March 2015).

5. Pankratova N.D., Nedashkovskaya N.I. Hybrid Method of Multicriteria Evaluation of Decision Alternatives. Cybernetics and Systems Analysis, 2014, vol. 50, issue 5, pp. 701-711.

6. Le Huede F., Grabisch M., Labreuche C., Saveant P. MCS - a New Algorithm for Multicriteria Optimisation in Constraint Programming. Annals of Operations Research, 2006, vol. 147, issue 1, pp. 143-174.

7. Rastrigin L.A., Ehjduk Ya.Yu. Adaptive Methods of Multicriteria Optimization. Automation and Remote Control, 1985, vol. 46, pp. 1-21.

8. Timofeev A.V., Dimitrichenko D.P. [Models and Methods for Multi-Criteria Optimization of Alternatives]. SPIIRAS Proceedings, 2008, vol. 7, pp. 182-194. (in Russian).

9. Berezovskii B.A., Kempner L.M. Nested Models of Multicriterial Optimization with Priority-Ordered Criteria. Automation and Remote Control, 1981, vol. 42, no. 1, pp. 83-90.

10. Melamed I.I. A Linear Convolution of Criteria in Multicriterial Optimization. Automation and Remote Control, 1997, vol. 58, no. 9, pp. 1499-1504.

11. Podinovskii V.V. The Quantitative Importance of Criteria. Automation and Remote Control, 2000, vol. 61, no. 5, pp. 817-828.

12. Zopounidis C., Doumpos M. Multicriteria Decision Systems for Financial Problems. TOP, 2013, vol. 21, issue 2, pp. 241-261.

13. Engau A., Moffatt C., Dyk W. Multicriteria Modeling and Tradeoff Analysis for Oil Load Dispatch and Hauling Operations at Noble Energy. Optimization and Engineering, 2015, vol. 16, issue 1, pp. 73-101.

14. Volin Yu.M., Ostrovskii G.M. Multicriteria Optimization of Technological Processes under Uncertainty Conditions. Automation and Remote Control, 2007, vol. 68, no. 3, pp. 523-538. DOI: 10.1134/S0005117907030125

15. Gurin L.G. On Multicriterial Optimization Problems under Uncertainty. Computational Mathematics and Mathematical Physics, 2004, vol. 44, no. 8, pp. 1284-1290.

Oksana S. Logunova, doctor of technical sciences, professor, department of Computer Engineering and Software Engineering, Nosov Magnitogorsk State Technical University, Magnitogorsk, Russian Federation, logunova66@mail.ru. 
Natalia S. Sibileva, master degree student, department of Computer Engineering and Software Engineering, Nosov Magnitogorsk State Technical University, Magnitogorsk, Russian Federation, natus224@gmail.com.

Received Desember 1, 2015

УДК 519.688

DOI: $10.14529 /$ jcem150401

\title{
РЕЗУЛЬТАТЫ ПАТЕНТНО-АНАЛИТИЧЕСКОГО ИССЛЕДОВАНИЯ ЗАДАЧИ ТРАНСФОРМАЦИИ СЛОЖНО-СТРУКТУРИРОВАННОЙ СМЕСИ
}

\author{
О.С. Логунова, Н.С. Сибилева
}

\begin{abstract}
В работе приводятся и систематизируются результаты патентного и аналитического исследований задачи трансформации сложно-структурированной смеси. Производится отбор и анализ наиболее эффективных научно-технических достижений в области исследования. Также, приводятся обобщенные результаты поиска и отбора наиболее значимых для исследования источников периодической печати (включая зарубежные издания). В качестве системного анализа приводятся обобщенные диаграммы анализа научных работ по году издания и по стране публикации. Результаты, полученные в ходе проведенных исследований, позволяют получить адекватное представление о текущих разработках в области работ со сложно-структурированными смесями, определить степень развития данной области, а также задать вектор для дальнейших работ по исследованию задачи трансформации сложно-структурированной смеси.

Ключевые слова: патентно-аналитическое исследование; многокритериальная оптимизация; линейное программирование; сложно-структурированная смесъ.
\end{abstract}

\section{Литература}

1. Сибилева, Н.С. Теоретико-множественная модель взаимодействия компонентов сложно-структурированной смеси / Н.С. Сибилева, О.С. Логунова, В.В. Павлов // Автоматизированные технологии и производства. - 2015. - № 2 (8). C. $25-27$.

2. Логунова, О.С. Стратегия постановки задачи многокритериальной оптимизации состава шихтовых материалов для электродуговой сталеплавильной печи / О.С. Логунова, Е.Г. Филиппов, И.В. Павлов, В.В. Павлов // Известия вузов. Черная металлургия. - 2013. - № 1. - С. 66-70.

3. Логунова, О.С. Результаты сравнительного анализа решения многокритериальной задачи оптимизации для расчета структуры шихтовых материалов дуговой сталеплавильной печи / О.С. Логунова, Н.С. Сибилева, В.В. Павлов // Математическое и программное обеспечение систем в промышленной и социальной cферах. - 2014. - № 2. - C. 54-64.

4. Федеральный институт промышленной собственности (ФИПС). - URL: http://www1.fips.ru. (дата обращения: 13 марта 2015 г.). 
5. Pankratova, N.D. Hybrid Method of Multicriteria Evaluation of Decision Alternatives / N.D. Pankratova, N.I. Nedashkovskaya // Cybernetics and Systems Analysis. - 2014. - V. 2. - Issue 5. - P. 701-711.

6. Le Huede, F. MCS - A New Algorithm for Multicriteria Optimisation in Constraint Programming / F. Le Huede, M. Grabisch, C. Labreuche, P. Saveant // Annals of Operations Research. - 2006. - V. 147. - Issue 1. - P. 143-174.

7. Растригин, Л.А. Адаптивные методы многокритериальной оптимизации Л.А. Растригин, Я.Ю. Эйдук // Автоматика и телемеханика. - 1985. - № 1. C. 5-26.

8. Тимофеев, А.В. Модели и методы многокритериальной оптимизации альтернатив / А.В. Тимофеев, Д.П. Димитриченко // Труды СПИИРАН. - 2008. - № 7. C. $182-194$.

9. Березовский, Б.А. Вложенные модели многокритериальной оптимизации с упорядоченными по важности критериями / Б.А. Березовский, Л.М. Кемпнер // Автоматика и телемеханика. - 1981. - № 1. - С. 105-112.

10. Меламед, И.И. Линейная свертка критериев в многокритериальной оптимизации / И.И. Меламед, Л.М. Кемпнер // Автоматика и телемеханика. - 1997. № 9. - С. 119-125.

11. Подиновский, В.В. Количественная важность критериев / В.В. Подиновский // Автоматика и телемеханика. - 2000. - № 5. - С. 110-123.

12. Zopounidis, C. Multicriteria Decision Systems for Financial Problems / C. Zopounidis, M. Doumpos // TOP. - 2013. - V. 21. - Issue 2. - P. 241-261.

13. Engau, A. Multicriteria Modeling and Tradeoff Analysis for Oil Load Dispatch and Hauling Operations at Noble Energy / A. Engau, C. Moffatt, W. Dyk // Optimization and Engineering. - 2015. - V. 16. - Issue 1. - P. 73-101.

14. Волин, Ю.М. Многокритериальная оптимизация технологических процессов в условиях неопределенности / Ю.М. Волин, Г.М. Островский // Автоматика и телемеханика. - 2007. - № 3. - С. 165-180.

15. Гурин, Л.Г. О задачах многокритериальной оптимизации в условиях неопределенности / Л.Г. Гурин // Журнал вычислительной математики и математической физики. - 2004. - Т. 44, № 8. - С. 1356-1363.

Логунова Оксана Сергеевна, доктор технических наук, профессор, кафедра вычислительной техники и программирования, Магнитогорский государственный технический университет имени Г.И. Носова (г. Магнитогорск, Российская Федеpauuя), logunova66@mail.ru.

Сибилева Наталъя Сергеевна, магистрант, кафедра вычислителъной техники и программирования, Магнитогорский государственный технический университет имени Г.И. Носова (г. Магнитогорск, Российская Федерация), natus224@gmail.com.

Поступила в редакцию 1 декабря 2015. 